\title{
Strategi Diplomasi Pertahanan Indonesia - Korea Selatan Dalam Memperkuat Pertahanan
}

Negara

\author{
Cheryl Manafe \\ Universitas Pertahanan. Kawasan IPSC Sentul, Sukahati, Citeureup, Bogor, Jawa Barat 16810, \\ Indonesia
}

cheryl.manafe@gmail.com

\begin{abstract}
Abstrak
Selain memperkuat pertahanan negara, kerjasama pertahanan juga membangun kepercayaan antara satu negara dengan negara lain. Kepercayaan tersebut dapat membuka kerjasamakerjasama dalam bidang lain seperti kerjasama ekonomi maupun pendidikan. Kerjasama internasional juga membantu menjaga perdamaian dunia. Indonesia dalam sektor pertahanan masih membutuhkan bantuan dari negara lain. Mitra kerjasama bilateral dalam bidang pertahanan Indonesia adalah Korea Selatan. Penelitian ini menggunakan Metodologi Kualitatif dengan menggunakan landasan teori yaitu Teori Kerjasama Internasional dan Teori Diplomasi Pertahanan. Strategi Diplomasi pertahanan Indonesia meliputi kerjasama antara Indonesia dan Korea Selatan yang terbilang berhasil dalam bidang industri pertahanan dalam transfer of technology dan pengadaan alutsista, pengembangan kualitas prajurit dengan latihan gabungan termasuk dalam kerjasama dalam membangun Cyber University dalam rangka menghasilkan tenaga ahli dalam bidang keamanan siber. Diharapkan kerjasama ini dapat membantu Indonesia mencapai misinya dalam kemandirian industri dan dalam menghadapi tantangan revolusi Industri 4.0 di masa depan
\end{abstract}

Kata Kunci: Diplomasi Pertahanan, Indonesia, Korea Selatan

\section{Latar Belakang}

Tuntutan yang menonjol dalam dunia internasional adalah perlunya sistem pemerintahan demokratis, dalam realitas politik terdapat hubungan antar bangsa yang saling berhubungan. Terdapat perubahan sosial dan budaya global yang menuntut kebebasan, kesetaraan, perlakuan yang adil untuk memperbaiki kualitas hidup manusia, serta tuntutan adanya kebebasan ekonomi, pasar, dan investasi (Sumarlan, 2019) karena pada dasarnya setiap negara ingin mengekspansi kekuatannya tidak hanya dari segi pertahanan dan keamanan, namun juga dari segi perekonomian, karena ekonomi merupakan faktor penentu pembangunan suatu negara dan kestabilan kondisi internal dari negara. Hal ini dilakukan untuk mencapai tujuan nasional dari negara tersebut

Perubahan konstelasi politik dunia dewasa ini membawa perubahan dalam hubungan antar elemen-elemen yang terdapat dalam tataran hubungan internasional. Dalam membentuk suatu negara dibutuhkan pemerintahan yang berdaulat. Pemerintahan yang berdaulat adalah pemerintahan yang memiliki kekuasaan baik di dalam negaranya maupun diluar. Hal ini diperlukan karena dalam membentuk suatu negara seringkali terjadi konflik, baik konflik eksternal yaitu konflik yang datang dari pengaruh luar negeri, maupun konflik internal yaitu konflik yang datang dari dalam negeri.

Pola-pola interaksi yang terjadi dalam dinamika hubungan internasional disebut dengan sistem internasional. Sistem Internasional menggambarkan hal-hal yang terjadi dalam dinamika internasional. Semakin berkembangnya dinamika politik internasional maka akan semakin berkembang pula sistem internasionalnya. Sistem internasional menurut berbagai perspektif dijalankan oleh aktor-aktor yang terlibat di dalamnya. Namun, setiap perspektif memiliki pandangan yang berbeda terhadap peran para aktor-aktor tersebut. Sistem Internasional secara 
sederhana dapat didefinisikan sebagai sistem yang mengatur hubungan antarnegara bangsa.

Dunia internasional dalam 10 tahun terakhir memiliki dinamika yang tidak stabil. Menurut Dino Patti Djalal, akibat perang dingin yang timbul antara hubungan negara-negara besar seperti China, Rusia, dan Amerika, kegiatan politik luar negeri sedang tidak stabil. Sedangkan pertumbuhan ekonomi dalam negeri sangat dipengaruhi oleh dinamika politik dunia (TribunNews, 2014). Jadi dapat disimpulkan bahwa politik dan ekonomi akan selalu berkorelasi. Sistem internasional saat ini juga sedang mengalami dinamika yang tidak biasa. Semenjak Donald Trump terpilih menjadi presiden Amerika Serikat ditambah lagi dengan perang dagang antara Amerika Serikat dengan China dan permasalahan imigran serta isu-isu lingkungan maupun isuisu hak asasi manusia yang saat ini sedang marak yaitu permasalahan hak asasi kaum Igbt. Setiap isu-isu tersebut saling mempengaruhi isu-isu lainnya dalam sistem internasional. Dalam problematika hubungan internasional akan selalu dihadapkan oleh konflik-konflik yang terjadi setiap harinya. Namun dalam setahun terakhir ini, konflik yang dihadapkan berdampak bagai domino mulai dari satu hal ke hal lainnya.

Seperti yang kita ketahui bahwa suatu negara tidak dapat berdiri sendiri dan membutuhkan negara lain dalam memenuhi kepentingan nasionalnya. Selain memperkuat pertahanan negara, kerjasama pertahanan juga membangun kepercayaan antara satu negara dengan negara lain. Kepercayaan tersebut dapat membuka kerjasamakerjasama dalam bidang lain seperti kerjasama ekonomi maupun pendidikan. Kerjasama internasional juga membantu menjaga perdamaian dunia. Indonesia dalam sektor pertahanan masih membutuhkan bantuan dari negara lain. Bantuan tersebut dapat dari sektor teknologi maupun dalam usaha pengadaan alutsista dan pelatihan prajurit. Salah satu mitra kerjasama pertahanan Indonesia adalah Korea Selatan.

\section{Rumusan Masalah}

Berdasarkan latar belakang di atas dapat diambil rumusan masalah yaitu, Bagaimana strategi diplomasi pertahanan Indonesia-
Korea Selatan dalam menghadapi dinamika internasional saat ini?

\section{Metode Penelitian dan Kerangka Teori}

Metode yang digunakan dalam penelitian ini adalah metode kualitatif. Data yang digunakan dalam penelitian ini adalah studi kepustakaan dengan mencari data dari buku, dokumen, arsip, internet, laporan, dan bacaan lainnya yang digunakan untuk memperoleh data terkait penelitian yang dibahas. Teori yang digunakan dalam penelitian ini adalah Teori Kerjasama Internasional dalam membahas hubungan bilateral kedua negara serta Teori Diplomasi Pertahanan dalam menjelaskan strategi pertahanan Indonesia dalam kerjasama pertahanan dengan Korea Selatan.

\section{Tujuan Penelitian}

Tujuan dari penelitian ini adalah mengetahui strategi diplomasi pertahanan Indonesia dan Korea Selatan dalam bidang pertahanan, perkembangannya di masa kini, dan manfaatnya dalam misi Indonesia yaitu mencapai kemandirian Industri Pertahanan dalam rangka menyambut Revolusi Industri 4.0.

\section{Manfaat Penelitian}

Manfaat dari penelitian ini adalah sebagai bahan untuk menambah wawasan para akademisi serta sebagai masukan bagi masyarakat untuk mengkaji permasalahan internasional yang terjadi saat ini terutama dalam bidang pertahanan negara.

\section{Diplomasi Pertahanan Sebagai Strategi Pertahanan Negara}

Saat ini isu-isu terorisme internasional dapat mengancam keamanan nasional bangsa (seperti: kelompok anarkis, kejahatan siber, ancaman nuklir, dan spionase) kegiatan politik, fenomena, dan konflik di dalam negeri dapat membuat kondisi suatu negara menjadi tidak kondusif. Hal ini dapat berakibat dengan tidak stabilnya kondisi politik suatu negara. Seperti yang kita ketahui bahwa kegiatan politik suatu negara sangat berpengaruh pada perekonomian suatu negara dan perekonomian suatu negara berpengaruh pada kekuatan militernya. Hal tersebut dapat 
berakibat pada menurunnya kredibilitas negara tersebut.

Untuk mengatasi dinamika tersebut dibutuhkan strategi diplomasi pertahanan. Diplomasi merupakan tahap untuk mencegah perang dan memenuhi kepentingan nasional suatu bangsa. Pada hakikatnya suatu negara saling membutuhkan negara lain untuk dapat berdiri dan mencapai kepentingan nasionalnya. Diplomasi menjadi jalan untuk mencapai hal tersebut. Diplomasi merupakan 'senjata' dalam sistem internasional.

Seperti yang kita ketahui diplomasi merupakan seni bernegosiasi yang biasa dilakukan oleh negara untuk mencapai kepentingan nasionalnya biasanya diwakilkan oleh seorang diplomat. Sedangkan diplomasi pertahanan merupakan aktivitas kerjasama baik secara bilateral maupun multilateral yang bertujuan untuk menjaga keamanan, perjuangan hak asasi manusia, tanggap, bencana alam, maupun penegakan keamanan. Menurut Panglima TNI, Diplomasi pertahanan merupakan alat penting dalam kebijakan keamanan luar negeri karena saat ini dengan keterbatasan alutsista bagi negaranegara berkembang perlu bekerjasama dengan negara-negara maju dalam hal pengadaan alutsista dan teknologi untuk memperkuat pertahanan negara. Military diplomacy yang dilakukan TNI antara lain pengerahan Prajurit Garuda pada misi perdamaian dunia, dengan soft power yang khas sehingga membuat kontingen Garuda senantiasa memiliki daya tarik tersendiri dibandingkan dengan kontingen negara lain (TribunNews, 2014).

Salah satu bentuk strategi diplomasi pertahanan Indonesia antara lain adalah kerjasama industri pertahanan (joint production, transfer of technology, to increase defense capabilities), pelatihan prajurit (confidence building measures, joint training), pengiriman pasukan ke luar negeri dalam misi perdamaian. Sebagaimana telah dijelaskan dalam Buku Putih Pertahanan Negara, hal ini merupakan implementasi dari prinsip pertahanan negara bahwa tiap tiap militer dan non-militer yang merupakan komponenkomponen wajib turut serta untuk usaha pertahanan negara. Dikarenakan keterbatasan alutsista dan dinamika sistem internasional yang semakin lama semakin berkembang maka sudah seharusnya pemerintah terus bekerjasama dengan pihakpihak lain seperti negara-negara yang memiliki pertahanan yang kuat sehingga Negara Indonesia dapat mempertahankan kedaulatannya dalam dinamika internasional yang selalu diiringi konflik baik konflik internal maupun eksternal (Buku Putih Pertahanan Negara, 2015).

Dilihat dari dinamika sistem internasional saat ini dan dalam sepuluh tahun terakhir, maka dibutuhkan strategi pertahanan negara yang fleksibel dan adaptif. Dikarenakan kebutuhan akan strategi yang fleksibel karena pada saat ini dinamika yang terjadi dalam dunia internasional dapat berubah dengan cepat dan dapat melibatkan banyak aspek. Dengan semakin berkembangnya teknologi maka akan semakin dibutuhkannya teknologi yang mutakhir bagi pertahanan negara. Jika suatu negara belum dapat memenuhi hal tersebut maka dapat melakukan kerjasama dengan negara lain yang menguasai hal tersebut sehingga tercipta win win solution antara kedua negara.

\subsection{Kerjasama Indonesia dengan Korea Selatan}

Indonesia dengan Korea Selatan merupakan mitra kerjasama dengan tingkat kerjasama yang terus meningkat dari tahun ke tahun. Tentu saja kepercayaan yang dibangun kedua pihak akan semakin memudahkan Indonesia dan Korea Selatan dalam membangun kerjasama dalam berbagai bidang, khususnya dalam bidang pertahanan. Indonesia dan Korea Selatan juga mempunya visi dan misi serta budaya yang selaras. Hal ini semakin memperkuat hubungan bilateral kedua negara. Indonesia dan Korea Selatan sudah memasuki kerjasama tertinggi dalam hubungan bilateral kedua negara. kerjasama tersebut adalah dalam bidang industri pertahanan. Dimana kedua negara akan saling terbuka dalam strategi pertahanan masing-masing dan saling bekerjasama dalam pengadaan alutsista dan teknologi militer.

\subsubsection{Defense Diplomacy for Defense Industry}

Dalam industri pertahanan (Defense Diplomacy for Defence Industry), Indonesia

Volume 4 Nomor 1, September 2019 | 26 
dan Korea Selatan bekerjasama dalam pembuatan kapal selam, Pesawat T50 dan Pesawat Tempur KFX/IFX (Kemhan, 2018). Hal tersebut dapat membantu Indonesia dalam mengembangkan teknologi pertahanan dan menambah alutsista mengingat bahwa saat ini di era globalisasi dan perkembangan teknologi yang sangat pesat mengharuskan setiap negara untuk selalu mengikuti perkembangan zaman agar tidak tertinggal dan dapat mempertahankan kedaulatannya dalam kancah internasional. Dengan adanya kerjasama industri pertahanan dengan Korea Selatan diharapkan Indonesia dapat mengembangkan teknologi dalam negeri dan menjadikan Indonesia lebih mandiri dalam bidang industri pertahanan di masa depan dengan teknologi yang dapat bersaing dengan negara-negara lain.

\subsubsection{Defense Diplomacy for Defense Capabilities}

Selain itu Indonesia juga mengadakan pelatihan gabungan prajurit (Defense Diplomacy for Defense Capabilities) pelatihan gabungan tersebut dilaksanakan oleh prajurit Kopassus dengan Prajurit Korea Selatan dimana pelatihan tersebut dilaksanakan di suhu ekstrim untuk melatih prajurit Indonesia agar dapat bertarung dalam segala situasi dan cuaca (TribunNews, 2019). Dengan diadakannya pelatihan gabungan tersebut diharapkan Indonesia dan Korea Selatan dapat belajar teknik dan strategi pertahanan, serta pelatihan satu sama lain sehingga dapat saling meningkatkan kualitas prajurit masingmasing negara agar semakin meningkatkan pertahanan negara.

\subsubsection{Defense Diplomacy for Confidence Building Measures}

Indonesia juga bekerjasama dengan Korea Selatan dalam menghadapi permasalahan keamanan siber. Kekuatan pertahanan siber Korea Selatan sudah diakui di dunia dan Indonesia harus belajar dari Korea Selatan mengenai pertahanan siber mengingat saat ini perkembangan teknologi yang semakin pesat akan semakin memudahkan pihak-pihak yang tidak bertanggungjawab yang bertujuan untuk mengganggu kestabilan negara demi keuntungan pribadi. Dalam menghadapi ancaman siber tersebut, Indonesia dan Korea Selatan bekerjasama untuk membangun universitas siber di Indonesia (Kemenristekdikti, 2019). Dengan membangun Cyber University diharapkan dapat semakin meningkatkan minat rakyat Indonesia dalam bidang pertahanan siber dan menghasilkan tenaga-tenaga ahli dalam bidang siber untuk meningkatkan pertahanan negara dalam bidang siber mengingat bahwa saat ini tingkat ketergantungan masyarakat terhadap komputer dan internet sangatlah tinggi sehingga apabila terjadi serangan siber akan sangat berdampak pada kestabilan negara.

\section{Kesimpulan}

Kerjasama pertahanan Indonesia dan Korea Selatan terbilang berhasil. Kedua negara tidak hanya bekerjasama dalam peningkatan kualitas prajurit namun juga dalam bidang tertinggi dalam kerjasama pertahanan yaitu dalam bidang industri pertahanan. Selain itu kedua negara juga sepakat akan bekerjasama dalam membangun Cyber University yang dapat menghasilkan tenaga-tenaga ahli di bidang pertahanan siber. Dalam bidang pengadaan alutsista dari kerjasama Indonesia-Korea Selatan juga sangat membantu kinerja TNI dalam menjalankan tugas pokoknya. Diharapkan kedepannya dalam kerjasama pertahanan, Pemerintah Indonesia diharapkan dapat memperhatikan anggaran pertahanan Indonesia dalam kerjasama pertahanan dengan Korea Selatan serta diharapkan agar Indonesia dapat menggali ilmu dalam bidang teknologi untuk menyeimbangkan level teknologi Indonesia saat ini dengan Korea Selatan. Selain itu juga diharapkan agar Indonesia dapat menerapkan hal-hal yang dipelajari dalam kerjasama dengan Korea Selatan dalam membangun Industri pertahanan Indonesia menuju kemandirian industri dalam menghadapi tantangan revolusi industri 4.0 di masa yang akan datang.

\section{Daftar Pustaka}

Kementerian Pertahanan RI. 2015. Buku Putih Pertahanan Negara. Jakarta: Kementerian Pertahanan RI

Kementerian Pertahanan RI. 2018. Kerjasama Industri pertahanan, Korsel Tempatkan Indonesia Sebagai Partner

Volume 4 Nomor 1, September 2019 | 27 
Terbaik.[Online].https://www.kemhan. go.id/2018/05/03/keria-sama-industripertahanan-korsel-tempatkanindonesia-sebagai-partnerterbaik.html diakses 29 Mei 2019 Pukul 19.00

Kementerian Riset, Teknologi, dan Pendidikan Tinggi RI. 2019. IndonesiaKorea Selatan Menjejaki Kerja Sama CyberUniversity.[online].https://ristekd ikti.go.id/kabar/Indonesia-koreaselatan-menjajaki-kerja-sama-cyberuniversity/\#ybXoO72LZH1kS3W.99 di akses 29 mei 2019 pukul 20.30.

Sumarlan, Sutrimo. 2019. Presentasi Kelas Pertemuan 1 Introduction to Global Governance. Universitas Pertahanan. Sentul

Tribun News. 2014. Dino: 10 Tahun Terakhir Prestai Politik Indonesia Luar Biasa

[online].http://www.tribunnews.com/na sional/ 2014/10/16/dino-10-tahunterakhir-prestasi-politik-indonesialuar-biasa. Diakses 23 Mei 2019 pukul 15.31

Tribun News. 2014. Panglima TNI: Diplomasi Perahanan Alat Penting Kebijakan Keamanan Luar Negeri [online].

http://www.tribunnews.com/nasional/2 014/06/25/panglima-tni-diplomasipertahanan-alat-penting-kebijakankeamanan-luar-negeri. Diakses tanggal 23 Mei 2019 pukul 16.00

Tribun News. 2019. Ketika Kopassus di Suhu Ekstrim Malah Bikin Pasukan Korea Selatan Tercengan dan Kagum[online].http://jambi.tribunnews. com/2019/04/02/ketika-kopassus-disuhu-ekstrim-malah-bikin-pasukankhusus-korea-selatan-tercengan-dankagum diakses tanggal 29 mei 2019 pukul 19.52 